Review

\title{
The impact of intimate partner relationships on suicidal thoughts and behaviours: A systematic review
}

\author{
Dominique Kazan*, Alison L. Calear, Philip J. Batterham \\ National Institute for Mental Health Research, The Australian National University, Canberra, Australia
}

\section{A R T I C L E I N F O}

\section{Article history:}

Received 27 July 2015

Received in revised form

13 October 2015

Accepted 1 November 2015

Available online 4 November 2015

Keywords:

Intimate partner relationships

Suicide

Conflict

Separation

Systematic review

Risk factors

\begin{abstract}
A B S T R A C T
Background: A systematic review was conducted to identify the impact of intimate partner relationships on suicidality. The aim of the review was to identify factors within intimate partner relationships that influence suicidal ideation, attempts and completion.

Method: Fifty-one articles were identified through Scopus, PubMed and PsycINFO databases. Due to the high heterogeneity of the included studies, a narrative data synthesis was conducted.

Results: The research drew attention to specific contingents of the population, for example examining suicide risk in individuals under the age of 35 or lesbian, gay, bisexual and transgender (LGBT) individuals who are experiencing relationship discord, and in males who have recently separated. Limitations: Interpretation of these findings is constrained by methodological limitations prevalent in much of the literature. Limitations of the existing literature and corresponding directions for future research are discussed.

Conclusions: Relationship separation and poor quality relationships are likely to be important risk factors for suicidal thoughts and behaviours and are frequent triggers for a suicide attempt. This review highlights intimate partner relationships as a significant component in a suicide risk assessment, regardless of the clinical setting. Consequently, clinicians should be aware that individuals reporting relationship problems are likely to be at increased risk of suicidal thoughts and behaviours.
\end{abstract}

(c) 2015 Elsevier B.V. All rights reserved.

\section{Contents}

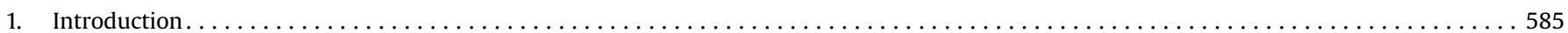

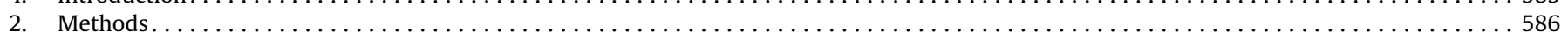

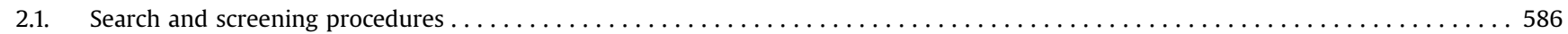

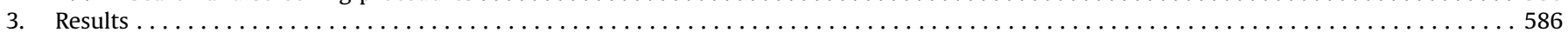

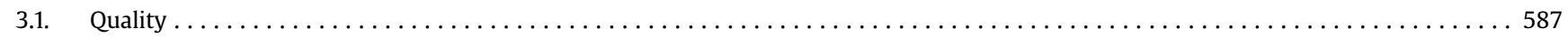

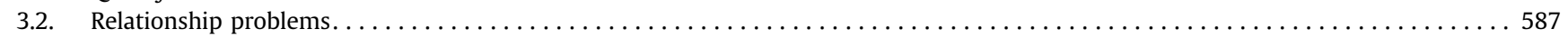

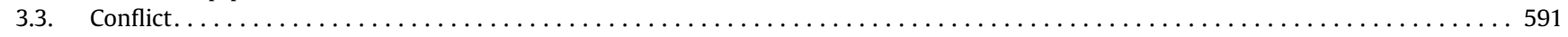

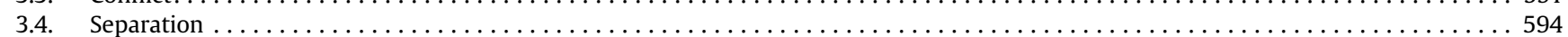

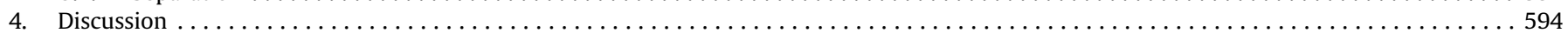

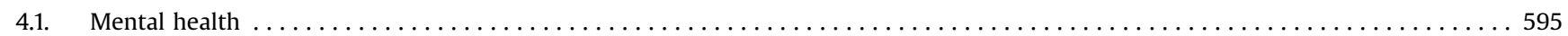

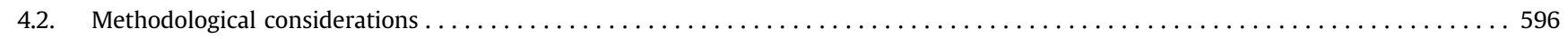

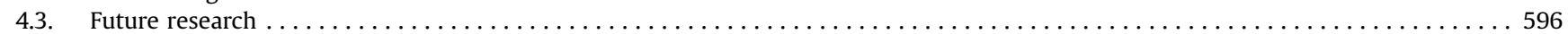

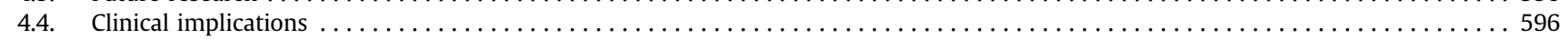

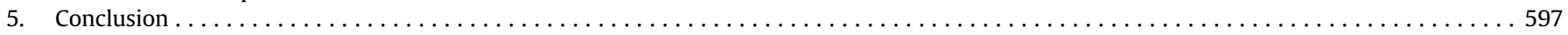

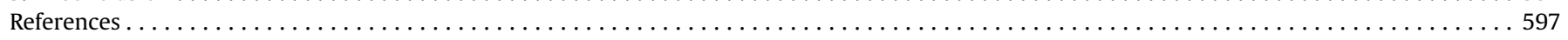

\footnotetext{
* Corresponding author.

E-mail address: Dominique.Kazan@anu.edu.au (D. Kazan).
} 


\section{Introduction}

Intimate partner relationships are an integral factor in the lives of many individuals, influencing the dynamic interplay between individual mental health and overall well-being (Whisman and Baucom, 2012). Around one-half of the Australian population, aged 15 years and older, are married (Australian Bureau of Statistics, 2012a) while the proportion of persons cohabiting has increased progressively from 6\% in 1986 to $16 \%$ in 2011 (Australian Institute for Family Studies, 2014). The United States of America reported a marriage rate of 6.8 per 1000 and a divorce rate of 3.6 per 1000 in 2012 (National Centre for Health Statistics, 2012), with an increase of $14 \%$ in the rate of cohabitation since 1995 to 2010 (Copen et al., 2012). In comparison, demographic data for the European Union shows that there has been a decline in the crude marriage rate, while the number of divorces has increased (Eurostat, 2014). Further, the proportion of births outside of marriage has increased across the European Union with an approximate $12 \%$ increase in births since 2000 (Eurostat, 2014). Although it is clear that trends in couple formation have changed dramatically over the twentieth century, the constant nature of the formation and dissolution of intimate partner relationships is a perpetual feature in the community landscape.

Suicide is currently the leading cause of death for Australians aged between 15 and 44 years (Australian Bureau of Statistics, $2012 \mathrm{~b}$ ) and is the second leading cause of death globally among 15 to 29 year olds (World Health Organisation, 2012). The purported association between suicidality and intimate partner relationships is grounded in empirical research that documents the influence of relationship factors on suicidality. For instance, studies have shown that low quality intimate partner relationships (Arcel et al., 1992), interpersonal conflict (Choi et al., 2013) and separation and/ or divorce (Wyder et al., 2009) are common precipitating factors to suicide. Furthermore, discord between two individuals in an intimate partner relationship is a prominent theme applicable to a range of cultural contexts.

Researchers have increasingly found that spouse or partner negative life events contribute significantly to suicidality (Bagge et al., 2013). Specifically, the effect of a relationship separation has been shown to have a significant increase in suicidal ideation and plans and/or attempts in the two years following separation (Batterham et al., 2014), with the risk particularly high for males aged 15 to 24 years (Wyder et al., 2009). These results are significant, as the divorce rate in Australia is highest in the under 30 age group for both men and women (Australian Institute for Family Studies, 2011) and the average age for a first divorce in America is 30 years (National Centre for Health Statistics, 2012).

The influence that a positive intimate partner relationship has on reciprocal mental health states can be significant. Studies have demonstrated that marital quality is positively associated with subjective well-being (Carr et al., 2014), and that positive romantic relationships influence physical health (Robles and Kiecolt-Glaser, 2003) and can be psychologically protective (Bookwala and Schulz, 1996; Markey et al., 2007). However, relationship discord is associated with the onset or maintenance of mental health problems, including depression (Whisman and Uebelacker, 2009) and subsequently poorer treatment outcomes (Whisman, 2013).

Several systematic reviews have been conducted to investigate specific elements of intimate partner relationships that are associated with suicidality, including intimate partner violence and abuse (Devries et al., 2013; McLaughlin et al., 2012) and separation (Ide, Wyder, Kõlves, \& De Leo, 2010). No review, however, has focused more broadly on intimate partner relationships as a whole and their influence on suicidality. The current systematic review aims to identify the factors within intimate partner relationships that influence suicidal ideation, attempts and completion.
Potential differences in gender, age and relationship status will also be explored. This review will assist in identifying gaps in the research literature and isolate potential targets for suicide prevention research in this area.

For the purpose of this review, a broad definition of intimate partner relationships will be adopted to capture the multifaceted nature of these relationships. As such, an intimate partner relationship is defined as: An interpersonal relationship between heterosexual and same-sex spouses, girlfriends or boyfriends (current and former) which involves physical and/or emotional intimacy.

\section{Methods}

\subsection{Search and screening procedures}

A systematic review of the literature was conducted to identify published studies that explore intimate partner relationships in the context of suicidality. Scopus, PubMed and PsycINFO databases were electronically searched, up to October 2014, with one or more of the following sets of terms: (i) partner relationship or intimate relationship or personal relationship or romantic relationship or dating AND suicid*; (ii) marriage or marital or divorce or separt* or relationship breakup or spouse AND suicid*; (iii) love or relationship disruption or relationship difficult* or relationship problem* AND suicid*. The titles and abstracts of the 9321 articles initially identified by these searches were screened by the primary author to determine their relevance to the review. Completely irrelevant articles that were unrelated to the topic of this review (i.e. did not discuss intimate partner relationships or suicide) were excluded at this stage, while relevant studies and reviews were retained and the full-text article examined. Additional articles were obtained from reference list searches. Fig. 1 presents a flowchart detailing the review process.

The inclusion criteria for the current review included: (i) measurement of intimate partner relationship factors (i.e. separation, conflict, and/or quality); (ii) measure of suicidal behaviours (ideation, plan, attempt and/or completion); (iii) tested the association between intimate partner relationships and suicidality; and (iv) the article was published in a peer-reviewed English language journal. Articles exploring intimate partner abuse and violence were excluded from the current review due to the recency of two systematic reviews (Devries et al., 2013; McLaughlin et al., 2012) explicitly exploring the relationship between these two factors. Articles were also excluded if intimate partner relationships were not distinguished from other general types of relationships (e.g. family, social or professional). Studies that fulfilled the inclusion criteria were coded by the primary author and one of three independent reviewers, with all relevant data collected and recorded.

\section{Results}

Overall, 51 empirical studies were identified that fulfilled the inclusion criteria. Of these, 18 (35\%) were retrospective studies, 15 (29\%) were cross-sectional, five (10\%) were qualitative, five $(10 \%)$ were longitudinal or prospective and eight (16\%) were case control or case crossover studies (see Table 1). Due to the heterogeneity among the included studies, analysis of the data was completed in the form of a narrative synthesis. This approach is considered appropriate for synthesising the results of studies with disparate study designs and aims (Hilari et al., 2012; Popay et al., 2006). The formation of themes were extracted according to key words used to describe the measure of relationship factors located within the 


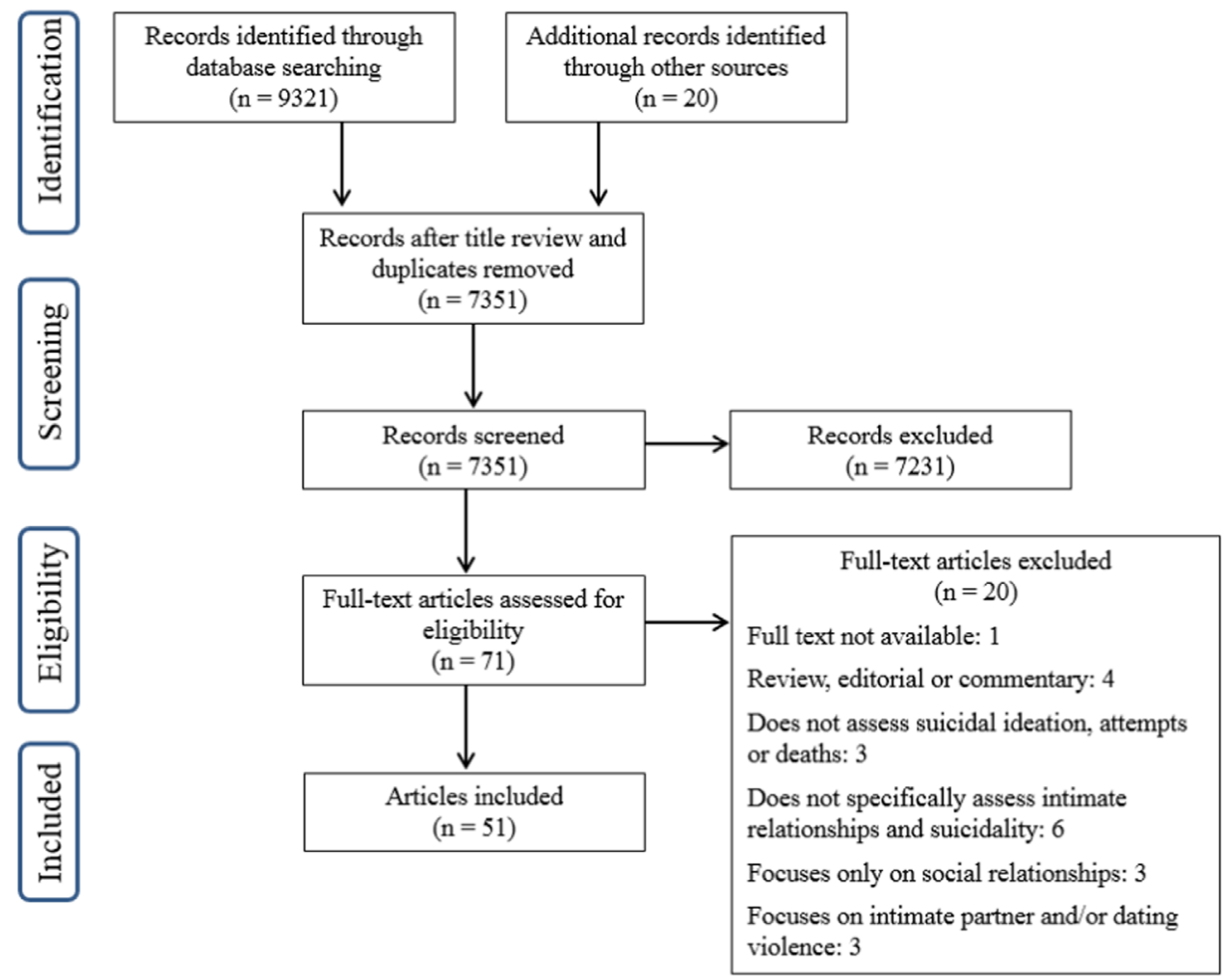

Fig. 1. PRISMA flow diagram.

reviewed articles. The themes were ordered to depict the progression of relationship factors found to contribute to suicidality. Tables 1-5

\subsection{Quality}

From the outset of a relationship, the perceived level of relational quality will influence all facets of intimate interaction. Although the concept of 'quality' is difficult to define within the broad context of intimate partner relationships, the studies identified highlighted inequity, authenticity, communication and overall low quality as indicators for suicidal thoughts, behaviours and completion.

Reporting on suicide death, Davis et al. (2009) found that people under 30 years were almost twice as likely to die by suicide in response to a perceived relationship inequity (i.e. the unequal contribution made to the relationship by each person), compared to those over 65 years who seldom mentioned relationship inequity as a reason for completing suicide. Canetto and Lester (2002) also found that love themes were significantly more common within suicide letters compared to achievement motives, independent of sex and age.

Soller (2014) reported that perceived relationship authenticity (incongruence between thoughts, feelings and actions within relational contexts) was associated with greater ideation and attempts, but only for females. He argued that the verification of interpersonal relationships has a heightened salience within the female role-identity, significantly influencing mental health. Also analysing a younger cohort, Sandberg-Thoma and Kamp Dush (2014) reported that adolescent suicidal ideation was not significantly associated with the number of romantic relationships in adulthood. Interestingly, participants who had initially reported suicidal ideation had a significantly decreased likelihood of future dissolution of cohabitation (Sandberg-Thoma and Kamp Dush, 2014). However, this study did not prospectively examine the quality of relationships or separation on later suicidal behaviours.

A specific factor pertinent to relationship quality was interpersonal communication between partners. Bonnar and McGee (1977) reported that the overall quality of interpersonal communication between spouses significantly contributed to the degree of suicidal behaviours. They observed that as the quality of interpersonal communication between spouses deteriorated (as perceived by the couple), the degree of suicidal behaviour increased (Bonnar and McGee, 1977). In support of this finding, Canetto et al. (1989) also reported 'moderate to severely' dysfunctional communication occurring in couples where a partner had identified high risk suicidal thoughts and/or behaviours. They argue that a lack of positive communication leads to an adoption of rigid defensive roles within the relationship, with suicidal behaviour occurring as a response to a series of interpersonal events (Canetto et al., 1989).

Overall poor or low quality intimate partner relationships were identified as a predominant factor in the suicide attempts of women hospitalised in Greece and Denmark (Arcel et al., 1992). Low quality was characterised by a high degree of psychological and physical violence, creating a sense of entrapment fuelled by shame, and ultimately leading to a suicide attempt as a means of escape (Arcel et al., 1992).

\subsection{Relationship problems}

Problems in the context of an intimate partner relationship can focus on an issue that is difficult to deal with and often a source of concern. Intrinsincly linked with poor quality relationships, tangible relationship problems (inclduing infidelity, rejection, abandonment etc.) appear to manifest over time and may be perceived as insurmountable by partners in the relationship.

Problems in a marriage or relationship was a major risk factor associated with suicide death within a number of retrospective studies (Busuttil et al., 1994; Logan et al., 2011). With Kurtaş et al. 


\begin{tabular}{|c|c|c|c|c|c|c|c|}
\hline $\begin{array}{l}\text { Author (published } \\
\text { year) Nation }\end{array}$ & $\begin{array}{l}\text { Participants and } \\
\text { settings }\end{array}$ & Size & $\begin{array}{l}\text { Age } \\
\% \\
\text { female }\end{array}$ & $\begin{array}{l}\text { Intimate partner } \\
\text { relationship }\end{array}$ & $\begin{array}{l}\text { Measure of relation- } \\
\text { ship factors }\end{array}$ & $\begin{array}{l}\text { Measure of } \\
\text { suicidality }\end{array}$ & Results \\
\hline $\begin{array}{l}\text { Busuttil et al. (1994) } \\
\text { UK (Scotland) }\end{array}$ & Community & 79 & $\begin{array}{l}19-74 \\
10.1 \%\end{array}$ & Married, de facto & Quality, conflict & Suicide death & $\begin{array}{l}\text { Psychiatric illness ( } 30.7 \%) \text {, problems in marriage or relationships } \\
\text { ( } 28.2 \% \text { ) and financial difficulties (16.7\%) were the major factors as- } \\
\text { sociated with suicide death. }\end{array}$ \\
\hline $\begin{array}{l}\text { Canetto et al. (2002) } \\
\text { USA }\end{array}$ & $\begin{array}{l}\text { Community (suicide } \\
\text { letter) }\end{array}$ & 56 & $\begin{array}{l}\text { Males: } \\
\text { M=30.4 } \\
\text { Female: } \\
M=36.6 \\
25 \%\end{array}$ & Not specified & $\begin{array}{l}\text { Conflict, separation, } \\
\text { quality }\end{array}$ & Suicide death & $\begin{array}{l}\text { Love themes were significantly more common in suicide notes than } \\
\text { achievement themes, independent of sex and age. }\end{array}$ \\
\hline $\begin{array}{l}\text { Cantor et al. (1995) } \\
\text { Australia }\end{array}$ & Community & 1375 & $15-55+21.2 \%$ & $\begin{array}{l}\text { Married, de facto, } \\
\text { widowed }\end{array}$ & Separation & Suicide death & $\begin{array}{l}\text { Separated males were six times more likely to suicide, and this was } \\
\text { greater in younger age groups. In the divorcee phase both male and } \\
\text { female rates were similarly elevated. Males may be particularly } \\
\text { vulnerable to suicide associated with interpersonal conflict in the } \\
\text { separation phase. }\end{array}$ \\
\hline $\begin{array}{l}\text { Chia et al. (2008) } \\
\text { Singapore }\end{array}$ & $\begin{array}{l}\text { Community (suicide } \\
\text { letter) }\end{array}$ & 1721 & $\begin{array}{l}\text { Letter: } \\
M=40.8 \\
S D=16.4 \\
35 \%\end{array}$ & Married and widowed & Separation, conflict & Suicide death & $\begin{array}{l}\text { Relationship problems in the age group } 10-24 \text { years were mainly } \\
\text { between family members. In the age group } 25-59 \text { years, marital } \\
\text { problems were more common, often associated with social problems } \\
\text { or infidelity. }\end{array}$ \\
\hline $\begin{array}{l}\text { Cupina (2009) New } \\
\text { Zealand }\end{array}$ & $\begin{array}{l}\text { Community } \\
\text { (retrospective) }\end{array}$ & 70 & $\begin{array}{l}18-65 \\
M=39.1 \\
S D=12.3 \\
51.4 \%\end{array}$ & Not specified & Separation, conflict & Self-report & $\begin{array}{l}\text { For } 86 \% \text { of women and } 85 \% \text { of men, separation from their partners } \\
\text { and relationship conflicts were the main stressors precipitating } \\
\text { suicidal behaviours. No gender differences in suicidal behaviours. }\end{array}$ \\
\hline Davis et al. (2009) USA & $\begin{array}{l}\text { Community (suicide } \\
\text { letter) }\end{array}$ & $\begin{array}{l}53 \text { (USA) } \\
264 \\
\text { (AUS) }\end{array}$ & Not specified & $\begin{array}{l}\text { Married, widowed, de } \\
\text { facto }\end{array}$ & Quality & Suicide death & $\begin{array}{l}\text { Those under age } 30 \text { were almost twice as likely to die by suicide in } \\
\text { response to perceived relationship inequity, whereas those over } 65 \\
\text { seldom mentioned relationship inequity as a reason for dying by } \\
\text { suicide. Relationship based suicides were the highest among those } \\
\text { who were either separated or divorced. }\end{array}$ \\
\hline $\begin{array}{l}\text { Heikkinen et al. (1992) } \\
\text { a Finland }\end{array}$ & Community & 400 & $\begin{array}{l}\text { Not specified } \\
21 \%\end{array}$ & Dating, de facto, married & Separation & Suicide death & $\begin{array}{l}\text { Separation during the preceding three months was the life event } \\
\text { most often perceived as precipitating the suicide. In } 68 \% \text { these cases, } \\
\text { the partners also rated it as a precipitant. When death and/or se- } \\
\text { paration were condensed into a broader category of interpersonal } \\
\text { loss, men had more often encountered such losses during the last } \\
\text { three months. }\end{array}$ \\
\hline $\begin{array}{l}\text { Heikkinen et al. (1992) } \\
\text { b Finland }\end{array}$ & Community & 388 & $\begin{array}{l}\text { Not specified } \\
21.4 \%\end{array}$ & Dating, de facto, married & Separation, conflict & Suicide death & $\begin{array}{l}\text { Interpersonal losses and conflicts were regarded as precipitant } \\
\text { stressors during the lifetime of } 40 \% \text { of male and } 35 \% \text { of female sui- } \\
\text { cides. Separation and interpersonal discord were more commonly } \\
\text { judged to be precipitant stressors for younger men than older men } \\
\text { whereas, no significant age differences were found in these stressors } \\
\text { among women. }\end{array}$ \\
\hline $\begin{array}{l}\text { Kaplan et al. (2012) } \\
\text { USA }\end{array}$ & Veterans & 8440 & $18-65+0 \%$ & Married, single & Conflict & Suicide death & $\begin{array}{l}\text { Nearly one of every two younger veteran suicide decedents ( } 18-34 \\
\text { years) experienced relationship problems shortly before death. By } \\
\text { contrast, older veteran decedents were more likely to have had } \\
\text { health problems. }\end{array}$ \\
\hline Karch et al. (2013) USA & Community & 1046 & $\begin{array}{l}10-17 \\
24.8 \%\end{array}$ & Dating & Conflict & Suicide death & $\begin{array}{l}\text { Intimate partner problems were evident for more than } 25 \% \text { of de- } \\
\text { cedents. However, intimate partner problems were not significantly } \\
\text { associated circumstances of suicide. }\end{array}$ \\
\hline $\begin{array}{l}\text { Kurtaş et al. (2012) } \\
\text { Turkey }\end{array}$ & $\begin{array}{l}\text { Community (suicide } \\
\text { letter) }\end{array}$ & 51 & $\begin{array}{l}16-72 \\
M=29.9 \\
S D=13.6 \\
45.1 \%\end{array}$ & $\begin{array}{l}\text { Dating, de facto, married, } \\
\text { widowed }\end{array}$ & Separation, conflict & Suicide death & $\begin{array}{l}\text { The most common event was separation from a spouse or a lover, } \\
\text { being cheated on or disagreement ( } 25.5 \%) \text {. In letters written by } \\
\text { males, suicide was mostly related to financial problems, while for } \\
\text { women it related to interpersonal relationship problems with a } \\
\text { spouse or boyfriend. }\end{array}$ \\
\hline $\begin{array}{l}\text { Lester et al. (2004) } \\
\text { Australia }\end{array}$ & $\begin{array}{l}\text { Community (suicide } \\
\text { letter) }\end{array}$ & 262 & $\begin{array}{l}\mathrm{M}=41.9 \\
\mathrm{SD}=17.3 \\
25.2 \%\end{array}$ & Not specified & Not specified & Suicide death & $\begin{array}{l}\text { Men more often had love/romantic problems. Women were sig- } \\
\text { nificantly more likely to have escape from unbearable pain as a } \\
\text { motive in their suicides. The suicides of older persons were more }\end{array}$ \\
\hline
\end{tabular}


Many decedents had a recent crises with interpersonal or other relationship problems in the absence of having known mental healt conditions, as indicated by classes 7 (criminal legal crises) and 8 (interpersonal crises). Further, class 7 had the highest proportion of decedents younger than 20 years.

\begin{tabular}{|c|c|c|c|c|c|c|c|}
\hline $\begin{array}{l}\text { Martin et al. (2013) } \\
\text { USA }\end{array}$ & Community & 100 & $\begin{array}{l}19-59 \\
M=31.6 \\
S D=8.4 \\
6 \%\end{array}$ & Married, divorced, single & $\begin{array}{l}\text { Conflict, separation, } \\
\text { infidelity }\end{array}$ & SDIT & $\begin{array}{l}\text { In the } 24 \text { hours prior to suicide } 34 \% \text { experienced the end of a ro- } \\
\text { mantic relationship, } 31 \% \text { an argument with spouse, } 17 \% \text { argument } \\
\text { with a significant other, } 9 \% \text { infidelity of a spouse, } 5 \% \text { infidelity of the } \\
\text { decedent and } 2 \% \text { physical fight with the spouse. The odds that a } \\
\text { decedent had interpersonal conflict in the } 24 \text { hours prior to death } \\
\text { were over twice as high among married individuals. }\end{array}$ \\
\hline $\begin{array}{l}\text { Séguin et al. (2014) } \\
\text { Canada }\end{array}$ & Community & 214 & $\begin{array}{l}M=37 \\
15 \%\end{array}$ & $\begin{array}{l}\text { Married, de facto, di- } \\
\text { vorced, single }\end{array}$ & Separation & Suicide death & $\begin{array}{l}\text { Individuals in one trajectory (high adversity, died earlier) were more } \\
\text { likely to have ended a love relationship than those in another tra- } \\
\text { jectory (lower burden of adversity). }\end{array}$ \\
\hline Shiner et al. (2009) UK & Community & 100 & $\begin{array}{l}M=46 \\
20 \%\end{array}$ & $\begin{array}{l}\text { Married, de facto, di- } \\
\text { vorced, single }\end{array}$ & Separation & Suicide death & $\begin{array}{l}\text { Relationship breakdown commonly occurs prior to suicide and is } \\
\text { often a trigger. However, it has a lesser impact on older adults and } \\
\text { women than on younger adults/men. }\end{array}$ \\
\hline $\begin{array}{l}\text { Runyan et al. (2003) } \\
\text { USA }\end{array}$ & Community & 882 & $\begin{array}{l}15-89 \\
M=41 \\
100 \%\end{array}$ & $\begin{array}{l}\text { Married, separated/di- } \\
\text { vorced, widowed, single }\end{array}$ & Conflict & Suicide death & $\begin{array}{l}\text { Being involved in interpersonal conflict was noted in } 17.7 \% \text { of cases } \\
\text { overall, and } 33.6 \% \text { of cases among women aged } 15-24 \text { years. In ad- } \\
\text { dition, interpersonal conflict was the second most common pre- } \\
\text { cursor noted by law enforcement officers (37.8\%) for all the cases. }\end{array}$ \\
\hline $\begin{array}{l}\text { Wyder et al. (2009) } \\
\text { Australia }\end{array}$ & Community & 6062 & $\begin{array}{l}15-65+\text { Not } \\
\text { specified }\end{array}$ & De facto, married & Separation & Suicide death & $\begin{array}{l}\text { For both males and females separation created a risk of suicide at } \\
\text { least four times higher than any other marital status. The risk was } \\
\text { particularly high for males aged } 15 \text { to } 24 \text {. }\end{array}$ \\
\hline
\end{tabular}

Note. $\mathrm{M}=$ mean; $\mathrm{SD}=$ standard deviation; $\mathrm{SDIT}=$ Suicide Death Investigation Template 
Table 2

Cross-sectional studies of intimate partner relationships and suicidality.

\begin{tabular}{|c|c|c|c|c|c|c|c|}
\hline $\begin{array}{l}\text { Author (published } \\
\text { year) Nation }\end{array}$ & $\begin{array}{l}\text { Participants and } \\
\text { settings }\end{array}$ & Size & $\begin{array}{l}\text { Age } \\
\% \\
\text { female }\end{array}$ & $\begin{array}{l}\text { Intimate partner } \\
\text { relationship }\end{array}$ & $\begin{array}{l}\text { Measure of relation- } \\
\text { ship factors }\end{array}$ & $\begin{array}{l}\text { Measure of } \\
\text { suicidality }\end{array}$ & Results \\
\hline $\begin{array}{l}\text { Arcel et al. (1992) } \\
\text { Greece and } \\
\text { Denmark }\end{array}$ & Inpatient & 56 & $\begin{array}{l}15-45 \\
100 \%\end{array}$ & $\begin{array}{l}\text { Married and steady } \\
\text { relationships }\end{array}$ & Quality & Self-report & $\begin{array}{l}\text { Quality of the intimate relationships was very low. A socially and } \\
\text { emotionally grounded inability to leave resulted in a suicide } \\
\text { attempt. }\end{array}$ \\
\hline $\begin{array}{l}\text { Bonnar et al. (1977) } \\
\text { USA }\end{array}$ & Community & 44 & $\begin{array}{l}\mathrm{N} / \mathrm{A} \\
50 \%\end{array}$ & Married & MCI & Self-report & $\begin{array}{l}\text { Quality of interpersonal communication between spouses sig- } \\
\text { nificantly deteriorated across the groups as the degree of suicidal } \\
\text { behaviour increased. }\end{array}$ \\
\hline $\begin{array}{l}\text { Canetto et al. (1989) } \\
\text { USA }\end{array}$ & Inpatient & 21 & $\begin{array}{l}20-68 \\
71 \%\end{array}$ & Married and de-facto & $\mathrm{MCI}$ & $\begin{array}{l}\text { SCL-90 and self- } \\
\text { report }\end{array}$ & $\begin{array}{l}\text { Perceived communication was significantly more dysfunctional } \\
\text { than that of the normative sample. }\end{array}$ \\
\hline $\begin{array}{l}\text { Choi et al. (2013) } \\
\text { Singapore }\end{array}$ & Inpatient & 228 & $\begin{array}{l}1 \text { st attempt } \\
\text { (64.9\%): } 45.3 \text { years } \\
\text { Multi attempt: } \\
\text { (35.1\%) } 36.7 \text { years }\end{array}$ & $\begin{array}{l}\text { Married, divorced, sepa- } \\
\text { rated, single and } \\
\text { widowed }\end{array}$ & Conflict & BERSA & $\begin{array}{l}53.6 \% \text { of first attempters and } 69.1 \% \text { of multi-attempters reported } \\
\text { interpersonal conflict/stress as a significant precipitating event to } \\
\text { their suicide attempt. Conflicting interpersonal relationships } \\
\text { were a significant predictor to multiple suicide attempts. }\end{array}$ \\
\hline $\begin{array}{l}\text { Edwards et al. (1981) } \\
\text { India }\end{array}$ & Inpatient & 100 & $\begin{array}{l}\mathrm{M}=24.4 \\
11-60 \\
75 \%\end{array}$ & Married, dating & Conflict, dispute & Self-report & $\begin{array}{l}\text { One of the major precipitants of parasuicide, and found in all } \\
\text { cases, was an interpersonal dispute. This involved marital or ro- } \\
\text { mantic relationships in } 81 \text { of the cases. }\end{array}$ \\
\hline $\begin{array}{l}\text { Fieldsend et al. (1981) } \\
\text { UK }\end{array}$ & Inpatient & 103 & $\begin{array}{l}\mathrm{N} / \mathrm{A} \\
81 \%\end{array}$ & $\begin{array}{l}\text { Married, de-facto, sepa- } \\
\text { rated divorced, widowed }\end{array}$ & Separation, quarrels & Self-report & $\begin{array}{l}\text { Quarrels were the most common key person event ( } 35 \% \text { ) with a } \\
\text { two-fold frequency difference between men and women (M } 20 \% \\
\text { and F } 39 \% \text { ). Separations were less common, but were more fre- } \\
\text { quent in men (M } 25 \% \text { and F5\%). }\end{array}$ \\
\hline Haw et al. (2008) & Inpatient & 4391 & $15-55+53 \%$ & Not specified & Conflict & SIS & $\begin{array}{l}\text { The most frequent life problem reported was the relationship } \\
\text { with spouse or partner. }\end{array}$ \\
\hline $\begin{array}{l}\text { Hyman et al. (2012) } \\
\text { USA }\end{array}$ & $\begin{array}{l}\text { Military (active } \\
\text { duty) }\end{array}$ & Not specified & $0 \%$ & Married, divorced & Separation, divorcee & $\begin{array}{l}\text { Self-report, suicide } \\
\text { death }\end{array}$ & $\begin{array}{l}\text { Separation or divorcee showed consistent association with sui- } \\
\text { cide across active duty personnel. }\end{array}$ \\
\hline $\begin{array}{l}\text { Krajnc et al. (1998) } \\
\text { Slovenia }\end{array}$ & Inpatient & 374 & $\begin{array}{l}9-18 \\
89.5 \%\end{array}$ & Dating & Separation & Self-report & $\begin{array}{l}21 \% \text { of all participants ascribed an attempted suicide to dis- } \\
\text { appointments, such as being abandoned by a boyfriend or falling } \\
\text { in love with the wrong person. }\end{array}$ \\
\hline $\begin{array}{l}\text { Lorensini et al. (2002) } \\
\text { Australia }\end{array}$ & Inpatient & 130 & $\begin{array}{l}\mathrm{N} / \mathrm{A} \\
55 \%\end{array}$ & $\begin{array}{l}\text { Married, de-facto, sepa- } \\
\text { rated divorced, widowed }\end{array}$ & $\begin{array}{l}\text { Separation, conflict and } \\
\text { quality }\end{array}$ & Self-report & $\begin{array}{l}\text { The threat of or actual separation was the most frequent reason } \\
\text { given for their suicide attempt for both men and women (38.4\%). } \\
\text { The second most frequent reason was partner conflict (24.6\%). }\end{array}$ \\
\hline $\begin{array}{l}\text { Mandal et al. (2012) } \\
\text { Poland }\end{array}$ & Inpatient & 35 & $\begin{array}{l}M=36.2 \\
S D=9.88 \\
100 \%\end{array}$ & $\begin{array}{l}\text { Married, single, divorced, } \\
\text { widowed }\end{array}$ & Attachment Style Test & Self-report & $\begin{array}{l}\text { The least frequently signalled type of difficulty was conflicts } \\
\text { between partners of a strong, but emotionally stormy relation- } \\
\text { ship (8.57\%). }\end{array}$ \\
\hline $\begin{array}{l}\text { Osvath et al. (2003) } \\
\text { WHO/EURO }\end{array}$ & Inpatient & 101 & $\begin{array}{l}17-75 \\
M=33.4 \\
S D=12.6 \\
62 \%\end{array}$ & $\begin{array}{l}\text { Married, de-facto, sepa- } \\
\text { rated divorced, widowed }\end{array}$ & Conflict and quality & Self-report & $\begin{array}{l}\text { The most reported traumatic life event preceding suicide was } \\
\text { 'relationship problems and conflicts' (94.1\%).The majority of adult } \\
\text { participants had serious marital conflicts with } 61.4 \% \text { of partici- } \\
\text { pants reporting 'relationship problems' and } 38.6 \% \text { reporting 'di- } \\
\text { vorcee' as 'the most stressful event'. }\end{array}$ \\
\hline Soller (2014) USA & Inpatient & 5316 & $\begin{array}{l}\mathrm{M}=15.9 \\
\mathrm{SD}=1.5 \\
54.6 \%\end{array}$ & Dating & $\begin{array}{l}\text { Quality and relationship } \\
\text { inauthenticity }\end{array}$ & Self-report & $\begin{array}{l}\text { Relationship inauthenticity was associated with greater ideation } \\
\text { and attempts for females only. Having an ongoing relationship } \\
\text { reduced ideation and attempts in females only. }\end{array}$ \\
\hline $\begin{array}{l}\text { Whisman et al. (2012) } \\
\text { USA }\end{array}$ & Inpatient & 2677 & $\begin{array}{l}15-54 \\
M=53.9 \\
S D=8.84 \\
53.9 \%\end{array}$ & Married, de-facto & $\begin{array}{l}\text { Quality (relationship } \\
\text { discord) }\end{array}$ & Self-report & $\begin{array}{l}\text { Participants with relationship discord had significantly higher } \\
\text { rates of suicidal ideation. However, the association between } \\
\text { discord and suicidal ideation was not significant when controlled } \\
\text { for a psychiatric disorder. }\end{array}$ \\
\hline $\begin{array}{l}\text { Weyrauch et al. (2001) } \\
\text { USA }\end{array}$ & Inpatient & 99 & $\begin{array}{l}16-76 \\
M=33.2 \\
S D=10.7 \\
40 \%\end{array}$ & Married, de-facto, dating & $\begin{array}{l}\text { Life Stressors/Pre- } \\
\text { cipitants Score Sheet }\end{array}$ & $\begin{array}{l}\text { SIS, The Risk Res- } \\
\text { cue Rating Scale }\end{array}$ & $\begin{array}{l}\text { Most common type of interpersonal conflict was with a boy- } \\
\text { friend, girlfriend, or spouse }(47 \%) \text {. Three or more interpersonal } \\
\text { losses were associated with less impulsive suicide attempts. The } \\
\text { pattern was not gender specific, nor was it associated. }\end{array}$ \\
\hline
\end{tabular}


(2012) observing that suicide letters written by men focused on financial problems, while for women interpersonal relationship problems with a spouse or boyfriend were more dominant. However, the contrary was reported by Lester et al. (2004) who found that men more frequently reported love or romantic problems, whereas women were more likely to have "escape from unbearable pain" as a motive in their suicides (p. 34). They also found that older people were more often motivated by 'escape from pain' than had love or romantic problems (Lester et al., 2004).

In terms of age, consistent associations between relationship problems and suicidal behaviour were reported. Although nonintimate partner relationship problems (e.g. one or both parents or friends) tended to play a significant role in suicidal behaviours among 10-24 year olds (Chia et al., 2008; Karch et al., 2013), disruption in the partner relationship was frequently reported as a common contributory antecedent to suicide death among 15 to 24 year olds (Houston et al., 2001). This finding was also culturally reflected in a sample of Iranian youth (14 to 17 years) who also expressed "difficulties in love" as their primary reason for attempting suicide (Keyvanara and Haghshenas, 2011). Further, relationship problems with a partner (Haw, 2008) and chronic relationship difficulties with a spouse (Daradkeh and Al-Zayer, 1988) were reported as common contributory factors for individuals around the age of 25 years. Of the one study focusing on an allmale veteran sample, one out of every two younger (18-34 years) veteran suicide decedents experienced intimate partner relationship problems shortly before death (Kaplan et al., 2012).

Osvath et al. (2003) reported that relationship problems and conflict with a partner was rated as the most common traumatic life event preceding a suicide attempt (94.1\%), outnumbering death and experience of losses (79.2\%) and mental (77.2\%) or physical abuse (65.3\%). Tavite and Tavite (2009) examined social factors contributing to suicidality on the small territory of Tokelau (a territory of New Zealand with significant suicide rates) and found that self-reported relationship problems including "marriage breakdown, affairs/betrayals and lack of spousal support" contributed to suicidal ideation and subsequent attempts (p. 72). Themes such as smothering love, infidelity, partner violence and denial of affection also contributed significantly to suicidal behaviour in Stephens (1985) study. Stephens (1985) also observed that younger participants tended to react to specific events by attempting suicide, whereas the older participants were more likely to be responding to long-term conflicts with their partners.

Beautrais et al. (1997) reported that beyond antecedent social, family or personality factors, suicide attempts were elevated by interpersonal relationship problems experienced during the previous year. In fact, the study reported that population attributable risk (PAR) estimates suggested that a potential decrease of up to $23 \%$ of suicide risk could be achieved if interpersonal difficulties were resolved. Bagge et al. (2013) reported that only spouse/ partner negative life events uniquely predicted suicide attempts when controlling for other specific negative life event categories. The study used a case crossover design to demonstrate that interpersonal negative life events are specific triggers for suicide attempts. More importantly, these results showed that interpersonal negative life events, involving a romantic partner, served as a trigger for engaging in suicidal behaviour for individuals not currently planning an attempt (Bagge et al., 2013).

\subsection{Conflict}

Conflict featured as a predominant theme leading to suicidality within intimate partner relationships. Interpersonal conflict (Runyan et al., 2003), quarrels (Fieldsend and Lowenstein, 1981) and relationship discord (Whisman and Uebelacker, 2006) were 
Table 4

Longitudinal and prospective studies of intimate partner relationships and suicidality.

\begin{tabular}{|c|c|c|c|c|c|c|c|}
\hline $\begin{array}{l}\text { Author (published } \\
\text { year) Nation }\end{array}$ & $\begin{array}{l}\text { Participants and } \\
\text { settings }\end{array}$ & Size & $\begin{array}{l}\text { Age } \\
\% \\
\text { female }\end{array}$ & $\begin{array}{l}\text { Intimate partner } \\
\text { relationship }\end{array}$ & $\begin{array}{l}\text { Measure of relationship } \\
\text { factors }\end{array}$ & $\begin{array}{l}\text { Measure of } \\
\text { suicidality }\end{array}$ & Results \\
\hline $\begin{array}{l}\text { Batterham et al. (2014) } \\
\text { Australia }\end{array}$ & Community & 6616 & $\begin{array}{l}24-68 \\
52.2 \%\end{array}$ & Married, de facto & Separation & PSF & $\begin{array}{l}\text { The effects of separation were strongest soon after separation, } \\
\text { with a nearly three-fold increase in ideation and an eight-fold } \\
\text { increase in plans/attempts in the two years following separation. } \\
\text { Effects were modified by age, gender or parental status. }\end{array}$ \\
\hline $\begin{array}{l}\text { Daradkeh et al. (1988) } \\
\text { Saudi Arabia }\end{array}$ & Inpatient & 33 & $\begin{array}{l}\mathrm{M}=24 \\
72.7 \%\end{array}$ & $\begin{array}{l}\text { Married, widowed, di- } \\
\text { vorced, single }\end{array}$ & $\begin{array}{l}\text { Disordered interpersonal } \\
\text { relationships }\end{array}$ & Self-report & $\begin{array}{l}\text { Disordered interpersonal relationships between the patients and } \\
\text { significant others such as spouses and parents stand out promi- } \\
\text { nently as a precipitating factor in suicidal behaviour. }\end{array}$ \\
\hline Hawton et al. (1988) UK & Inpatient & 1959 & $10-60+67 \%$ & Not specified & Separation, conflict & Self-report & $\begin{array}{l}\text { Recent disruption of a relationship with a partner was rare in the } \\
\text { suicide groups, as was a major row during the period immediately } \\
\text { preceding the index attempt. However, evidence of disruption in } \\
\text { the relationship with a partner during the previous year was age- } \\
\text { related, having occurred more often in younger subjects. }\end{array}$ \\
\hline $\begin{array}{l}\text { Sandberg-Thoma et al. } \\
\text { (2014) USA }\end{array}$ & School & 14146 & $\begin{array}{l}\mathrm{M}=21.7 \\
\mathrm{SD}=1.83 \\
\text { Wave } 3 \\
46 \%\end{array}$ & $\begin{array}{l}\text { Dating, de-facto, } \\
\text { married }\end{array}$ & Romantic relationships & Self-report & $\begin{array}{l}\text { Adolescent suicidal ideation was not significantly associated with } \\
\text { the number of romantic relationships in emerging adulthood. } \\
\text { Suicidal ideation significantly decreased the likelihood of dis- } \\
\text { solution of cohabitation. }\end{array}$ \\
\hline $\begin{array}{l}\text { Kõlves et al. (2012) } \\
\text { Australia }\end{array}$ & Community & 217 & $\begin{array}{l}\text { Males: } \\
\mathrm{M}=44.7 \\
\text { Female: } \\
\mathrm{M}=38.9 \\
40.1 \%\end{array}$ & Married, de-facto & $\begin{array}{l}\text { Relationship Breakdown and } \\
\text { Stressor Questionnaire }\end{array}$ & Self-report & $\begin{array}{l}\text { Separated males who showed an increase or stability in suicidality } \\
\text { were more affected by stressful experiences than males who were } \\
\text { not suicidal in either assessment. In both genders, suicidal beha- } \\
\text { viour was higher during the acute phase of separation and de- } \\
\text { creased significantly during the } 6 \text {-month follow-up. }\end{array}$ \\
\hline
\end{tabular}

Note. $\mathrm{M}=$ mean; $\mathrm{SD}=$ standard deviation; $\mathrm{PSF}=$ Psychiatric Symptom Frequency Scale 
Table 5

Case-control and case crossover studies of intimate partner relationships and suicidality.

\begin{tabular}{|c|c|c|c|c|c|c|}
\hline $\begin{array}{l}\text { Author (published } \\
\text { year) Nation }\end{array}$ & Participants and settings & $\begin{array}{l}\text { Age } \\
\% \\
\text { female }\end{array}$ & $\begin{array}{l}\text { Intimate partner } \\
\text { relationship }\end{array}$ & $\begin{array}{l}\text { Measure of relationship } \\
\text { factors }\end{array}$ & $\begin{array}{l}\text { Measure of } \\
\text { suicidality }\end{array}$ & Results \\
\hline $\begin{array}{l}\text { Beautrais et al. } \\
\text { (1997) New } \\
\text { Zealand }\end{array}$ & $\begin{array}{l}129 \text { suicide attempts admitted to hospital (153 ran- } \\
\text { domly selected community controls) }\end{array}$ & $\begin{array}{l}13-24 \\
\mathrm{M}=19.4 \\
\mathrm{SD}=3.0 \\
54.3 \%\end{array}$ & Dating & $\begin{array}{l}\text { List of Threatening } \\
\text { Experiences }\end{array}$ & Self-report & $\begin{array}{l}\text { With cases restricted to those aged } 18 \text { and older, using } \\
\text { self-report data, odds of serious suicide attempt were } \\
\text { elevated for those reporting interpersonal issues. }\end{array}$ \\
\hline $\begin{array}{l}\text { Brent et al. (1993) } \\
\text { USA }\end{array}$ & $\begin{array}{l}67 \text { families of suicide victims (decedents). } 67 \text { matched } \\
\text { community controls. }\end{array}$ & $\begin{array}{l}\mathrm{M}=17.1 \\
\mathrm{SD}=1.9 \\
85.1 \%\end{array}$ & Dating & $\begin{array}{l}\text { Interpersonal discord, } \\
\text { loss }\end{array}$ & Suicide death & $\begin{array}{l}\text { In the year before death, suicide completers were sig- } \\
\text { nificantly more likely to have experienced interpersonal } \\
\text { conflict with boy/girlfriends ( } 30.3 \% \text { compared to } 16.7 \% \\
\text { of controls) or disruption of a romantic attachment ( } 40 \% \\
\text { compared to } 20 \% \text { of controls). }\end{array}$ \\
\hline $\begin{array}{l}\text { Houston et al. } \\
\text { (2001) UK }\end{array}$ & $\begin{array}{l}27 \text { subjects whose deaths received a verdict of suicide or } \\
\text { undetermined cause. } 22 \text { male self-harm control group } \\
\text { subjects. }\end{array}$ & $\begin{array}{l}15-24 \\
13.5 \%\end{array}$ & Dating & Separation, conflict & Suicide death & $\begin{array}{l}\text { A substantial proportion of participants reported dis- } \\
\text { ruption in the relationship with a partner as an influ- } \\
\text { ence on suicide }(44.4 \% \text { ). The most frequent precipitants } \\
\text { within the week prior to death were difficulties in, or } \\
\text { the end of, a relationship. }\end{array}$ \\
\hline $\begin{array}{l}\text { Kõlves et al. (2011) } \\
\text { Australia }\end{array}$ & $\begin{array}{l}228 \text { males (study group) and } 142 \text { females (control group } \\
\text { 1) who were separated in the previous } 18 \text {-months and } \\
174 \text { males who were married/ de facto or single (control } \\
\text { group } 2\end{array}$ & $\begin{array}{l}\mathrm{M}(228) \\
\mathrm{M}=43.3 \\
\mathrm{SD}=10.0\end{array}$ & Separation & $\begin{array}{l}\text { The Relationship Break- } \\
\text { down Stressor } \\
\text { Questionnaire }\end{array}$ & $\begin{array}{l}\text { Paykel Suicide } \\
\text { Items }\end{array}$ & $\begin{array}{l}\text { The correlation between state shame and suicidality } \\
\text { was significantly lower for separated females compared } \\
\text { with separated males. Separated males were more } \\
\text { vulnerable to the experience of state shame in the } \\
\text { context of separation, which might lead to the devel- } \\
\text { opment of suicidality. }\end{array}$ \\
\hline $\begin{array}{l}\text { Paykel et al. (1975) } \\
\text { USA }\end{array}$ & $\begin{array}{l}53 \text { suicide attempts (hospital admission), } 53 \text { depression } \\
\text { and } 53 \text { community participants }\end{array}$ & $\begin{array}{l}18-65 \\
70 \%\end{array}$ & $\begin{array}{l}\text { Married, separated/ } \\
\text { divorced/widowed }\end{array}$ & Conflict & Self-report & $\begin{array}{l}\text { The frequency of 'serious arguments with spouse' was } \\
\text { reported significantly more by suicide attempters } \\
\text { compared with the general population and individuals } \\
\text { with depression. }\end{array}$ \\
\hline $\begin{array}{l}\text { Zhang et al. (2012) } \\
\text { China }\end{array}$ & $\begin{array}{l}392 \text { suicide cases (decedents) and } 416 \text { community living } \\
\text { controls of the same age range and from the same } \\
\text { counties were entered for study }\end{array}$ & $\begin{array}{l}15-34 \\
\text { Suicide: } 45.4 \% \\
\text { Control:51.4\% }\end{array}$ & $\begin{array}{l}\text { Dating, de-facto and } \\
\text { married }\end{array}$ & $\begin{array}{l}\text { Paykel's Interview for Re- } \\
\text { cent Life Events }\end{array}$ & Suicide death & $\begin{array}{l}\text { Marriage/love ( } 51.3 \%) \text { life events were most commonly } \\
\text { reported for both suicides and community living con- } \\
\text { trols. For suicide victims, the most frequent item in the } \\
\text { marriage/love item was 'quarrelling with partner } \\
(22.2 \%) \text {. }\end{array}$ \\
\hline $\begin{array}{l}\text { Skerrett et al. (2014) } \\
\text { Australia }\end{array}$ & $\begin{array}{l}35 \text { gay, bisexual and transgender suicide cases were } \\
\text { identified from the Queensland Suicide Register. Three } \\
\text { comparison cases of non-LGBT suicides for each LGBT } \\
\text { suicide were matched. }\end{array}$ & $\begin{array}{l}M=36.7 \\
28 \%\end{array}$ & $\begin{array}{l}\text { Same-sex dating, de } \\
\text { facto }\end{array}$ & Separation, conflict & Suicide death & $\begin{array}{l}\text { In terms of relationship problems overall, LGBT in- } \\
\text { dividuals experienced such problems in the majority of } \\
\text { cases }(65.7 \%) \text { compared with exactly one-third in } \\
\text { comparison cases. Within the category of relationship } \\
\text { problems, relationship conflict was significantly more } \\
\text { common in LGBT than in non-LGBT cases. }\end{array}$ \\
\hline \multicolumn{7}{|l|}{ Case Crossover } \\
\hline $\begin{array}{l}\text { Bagge et al. (2013) } \\
\text { USA }\end{array}$ & Inpatient & $\begin{array}{l}18-64 \\
M=36.39 \\
S D=11.3 \\
59 \%\end{array}$ & Spouse, partner & Negative life event & SIS & $\begin{array}{l}\text { An interpersonal NLE was uniquely related to a suicide } \\
\text { attempt when controlling for a non-interpersonal NLE. } \\
\text { However, only a spouse/partner NLE uniquely predicted } \\
\text { suicide attempts when controlling for other specific NLE } \\
\text { categories. }\end{array}$ \\
\hline
\end{tabular}

Note. $\mathrm{M}=$ mean; $\mathrm{SD}=$ standard deviation; $\mathrm{SIS}=$ Suicide Intent Scale; $\mathrm{NLE}=$ Negative Life Event. 
identified as known risk factors for suicidal thoughts and behaviours. Conflict was often protracted and an experience of a buildup of problems within the intimate partnership.

Disruption in the partner relationship was frequently reported as a precipitating factor to suicide death (Houston et al., 2001), with participants categorising quarrelling with partner (Zhang and Ma, 2012), interpersonal conflict with boy/girlfriends (Brent et al., 1993), and serious arguments with spouse (Paykel et al., 1975) as significant precipitants of suicide death when compared with control groups. Interpersonal conflict was the second most common precursor to suicide death with conflict predominantly occurring between the victim and her current or former intimate partner (Runyan et al., 2003). With Martin et al. (2013) reporting the odds that a decedent had interpersonal conflict in the 24 hours prior to death were over twice as high among married individuals.

Interpersonal disputes as a major precipitant of parasuicde were found in all cases interviewed by Edwards et al., (1981), with intimate partner conflict more frequent in the week preceding the attempt (Weyrauch et al., 2001). In addition, Paykel et al. (1975) reported that there was a marked peak of events in the month prior to the suicide attempt suggesting a particularly immediate link between event and reaction. Further, Brent et al. (1993) suggested that in the year before death, suicide completers were significantly more likely to have experienced interpersonal conflict or disruption of a romantic attachment compared to community controls. Findings of particular interest also included the report that conflicting interpersonal relationships were a significant predictor to multiple suicide attempts (Choi et al., 2013).

Mandal and Zalewska (2012) found that conflicts between partners of a "strong, but emotionally stormy relationship" were the least frequently signalled type of difficulty. However, the participants reported severe developmental trauma and adult experiences of intimate partner violence which could minimise the presence of relational conflict. Hawton and Fagg (1988) also reported that recent disruption of a relationship with a partner was rare in the suicide groups, as was a major row during the period immediately preceding the attempt. They further reported that physical health issues were more persistent and difficult to resolve, compared to relationship difficulties, and more often preceded a suicide attempt (Haw and Hawton, 2008). However, Hawton and Fagg (1988) did acknowledge that the evidence of disruption in the relationship with a partner was age-related and occurred more often in younger participants and more predominantly in males. In comparison, a study examining Iranian females aged 15 to 46 also demonstrated that "conflict between marital partners" and "failure in premarital relationships" emerged as prominent themes in the reasoning for attempting suicide - irrespective of law and traditional values (Keyvanara and Haghshenas, 2010, p.777). Interestingly, only one study examined LGBT intimate partner relationships and suicidality. This study found that intimate partner relationship conflict was a significantly more common precipitant to suicide when compared to non-LGBT cases (Skerrett et al., 2014).

\subsection{Separation}

Relationship separation featured as the most prominent factor contributing to increased suicidality across the review. The threat of, or actual, separation was the most frequent reason given for a suicide attempt among both genders (Lorensini and Bates, 2002) with Fieldsend and Lowenstein (1981) finding that separation, as a reason for suicide, was more frequent in men. Separation or divorce also showed consistent association with suicide across active duty personnel (Hyman et al., 2012), with younger age samples also attributing the attempted suicide to disappointments such as "being abandoned by a boyfriend" (Krajnc et al., 1998).
Furthermore, Weyrauch et al. (2001) reported that for all of their participants, a background of interpersonal loss and disruption occurred in the year preceding the suicide attempt. In Australia, the collection of data derived from calls made to a telephone counselling service showed that young males (under 35 years) were $75 \%$ more likely to report a relationship breakdown than were young females, with the majority of suicide calls pertaining to broken, strained or inadequate intimate relationships (Barber et al., 2004).

Additional findings of particular interest included studies exploring the specific impact of relationship separation on subsequent suicidality. Retrospective examination of patient files reported that for both women and men, separation from their partners was one of the main precipitants of suicidal behaviour (Cupina, 2009; Martin et al., 2013). Relationship separation was echoed as a critical precipitant to suicide death within the last three months prior to suicide (Heikkinen et al., 1992b) and if the participant experienced a high burden of adversity (Séguin et al., 2014).

Of particular note, males were six times more likely to suicide following separation and were more vulnerable to experience associated interpersonal conflict during this phase (Cantor and Slater, 1995; Heikkinen et al., 1992b). Deceased males were reported to be of younger age (Heikkinen et al., 1992a; Shiner et al., 2009), with the risk particularly high for males aged 15 to 24 years (Wyder et al., 2009). Males more likely identified relationship breakdown as the main trigger, rather than as a contributory factor to suicide, whereas females were more evenly divided between these two categories (Shiner et al., 2009). Marriage was reported as a protective factor in regards to suicidality (Cantor and Slater, 1995; Wyder et al., 2009), with divorced men also at a substantially higher risk of suicide, although this decreased with age (Wyder et al., 2009).

In terms of relationship separation, Batterham et al. (2014) reported that the effects of separation were strongest soon after the separation with nearly a three-fold increase in ideation and an eight-fold increase in plans/attempts in the two years following separation. Kõlves et al. (2012) echoed this finding reporting that the acute stage of marital/de facto separation increased the risk of developing suicidal behaviours. The period up to four years before a separation, when a relationship may be deteriorating, was also found to be a time of increased risk for suicidal thoughts and behaviours (Batterham et al., 2014). Furthermore, Batterham et al. (2014) observed that the "decrease of suicidal ideation and plans/ attempts among individuals more distal from separation suggest that the process of separation likely precipitates elevated risk for suicidality, rather than being a consequence of suicidality" (p.62). Kõlves et al. (2012) also reported that males presented higher levels of suicidality than females following separation. They observed that males who identified as being more affected by stressful experiences, exhibited an increase in suicidality (Kõlves et al., 2012). In support of previous research regarding separation, Houston et al. (2001) reported that the most frequent precipitants within the week prior to death were difficulties in, or the end of a relationship. Separation or disruption of a romantic attachment was significantly more common for young adult suicide victims when compared to controls (Brent et al., 1993). Also, separated males at risk of developing suicidal thoughts and behaviours were found to be more susceptible to the experience of 'state shame' (Kõlves et al., 2011).

\section{Discussion}

The importance of reviewing relationship factors in the context of suicidality was evident across a broad range of cultural contexts, 
clinical settings and retrospective studies. The review highlighted the pervasiveness of relationships issues, regardless of cultural or ethnic background, and the precipitant effect on suicidality. However, it is acknowledged that the reviewed evidence is not sufficiently robust to determine, with confidence, the factors that precede and predict suicide due to the limited number of prospective studies in the specified area.

The key findings from this review support the assertions made by existing systematic reviews examining suicidality and intimate partner abuse and violence. The associations between relationship separation and conflict, and suicidal ideation and/or behaviours, may be mediated by intimate partner violence with McLaughlin et al. (2012) reporting that irrespective of study design, there was a strong and consistent association between intimate partner abuse and suicidality. The findings that low quality relationships characterised by conflict, problems and arguments contribute to an increased risk of suicidality, is more acutely evidenced by the fact that these factors can quickly create an environment of abuse and violence. The pervasive influence of low quality relationships can render an individual helpless and hopeless, exacerbating vulnerability, particularly in females, which may lead to an increased risk of overall suicidality.

It is difficult to conclude with certainty the differentiating risk factors that distinguish whether a partner will engage in suicidal ideation, a suicide attempt or completion. The presence of an intimate partner relationship, where two individuals with unique personal backgrounds share an intimate emotional and physical bond, can be argued to be a risk factor if other conditions are met, including trauma history, mental illness, personality and complex attachment patterns. This is further complicated by past suicide history, the presence of intimate partner violence, social networks/support, socio-economic status, age, and sexual orientation. To place this information in context, the Diathesis Stress Model of Suicidal Behaviour can be applied to better formulate biological/genetic traits alongside environmental influences which may increase risk for suicidal behaviours. Yaseen et al., (2012) reported a positive association between "intense feelings of love, particularly in the absence of protective feelings of calm or positive self-view" and a resulting suicide attempt. The results suggesting that the interaction between internalised attachment representations, level of distress and coping mechanisms are all important mechanisms in understanding the interplay between emotional reactivity to intimate partner events and suicidality (Yaseen et al., 2012). It also highlights the way in which a psychosocial crisis, such as a relationship separation, can be a contributing factor to suicidal behaviours, contingent on predispositional vulnerability.

Due to the rapid changes in composition and size of an individual's social network following an intimate partner disruption, the Interpersonal Theory of Suicide is a useful theoretical framework to assess impact and suicide risk (Joiner, 2005; Van Orden et al., 2010). Poor relationship quality, increasing problems, chronic conflict and separation are all mechanisms which may exacerbate a lack of belongingness and self-blame which may lead to and/or intensify a sense of perceived burdensomeness. Further, although more studies are needed to investigate intimate relationship quality as a predictor to suicide attempts, Choi et al. (2013) reported that conflicting interpersonal relationships were a significant predictor to multiple suicide attempts which may increase an individuals' acquired capability for suicide, leading to more lethal attempts and suicide death (Harris and Barraclough, 1997; Owens et al., 2002). It is not news for clinicians that multiple suicide attempts are the primary predictor of suicide completion. However, applying the Interpersonal Theory of Suicide to clinical practice may provide a framework for organising client data and assist in identifying exacerbating factors.

The likely mechanisms through which intimate partner relationship issues contribute to suicide risk appears to be shaped by age, the nature of relationship problems, and time (including length of relationship and proximity to separation). Specifically, the review suggests that a younger cohort (under 35 years) tend to adopt a more impulsive reaction to relationship discord and partners of a separated relationship are also more likely to experience a sense of hopelessness which may lead to suicidality. These findings support research by Stack and Scourfield (2015) who reported that after controlling for psychiatric, social, and economic predictors of suicide completions, the odds of suicide increased by $60 \%$ one year after divorce, compared to a $30 \%$ increase for distal divorce. The prominence of relationship separation as a risk factor for suicide also supports findings from Ide et al. (2010) systematic review which asserts that the acute stage of separation and relationship difficulties in general, are high risk factors for suicide. This provides a more distinct clinical focus on individuals who no longer identify as being part of a marriage and who have separated, divorced, or are single.

It is also worthwhile to consider that there is a possibility that the emergence of suicidality in a relationship might impact on quality or lead to conflict and/or separation, that is, a bidirectional effect may exist. However, Batterham et al. (2014) found that the association between separation and suicidality did not reflect a selection effect. They reported that following a period of time post-separation, suicidal ideation and behaviours decreased, emphasising that the process of separation precipitates elevated risk and was not solely as a result of existing suicidality. Further, Sandberg-Thoma and Kamp Dush (2014) observed that individuals, who experienced suicidal ideation, also experienced a decrease in the likelihood of cohabitation dissolution, which suggests that the association between suicidal thoughts and behaviours may be unidirectional. Nevertheless, little additional research has evaluated the impact of suicidal thoughts and behaviours on the initiation, quality or maintenance of intimate partner relationships.

Associations between gender and relationship impact on suicidality were less clear, with the results inconsistently demonstrating gender differences. Although, more studies found males to be at a heightened risk of suicidal thoughts and behaviours following a recent separation compared to females, it is difficult to make the assertion that males are at an overall heightened risk of suicide as a result of broader relationship issues. The inconclusive gender finding supports a review conducted by Evans et al. (2014), who also stated that no definitive conclusion could be made regarding gender differentials in suicide risk following an intimate relationship breakdown.

Age appeared to influence the likelihood or emergence of suicidal thoughts and behaviours in response to relationship factors. Younger individuals tended to react to specific and more recent events involving partners, whereas older individuals were more likely to be responding to long-term partner conflicts (Stephens, 1985). Spousal relationship problems tended to become more prominent over the age of 25 , with a distinct drop in relationship enquiry and the prevalence of suicidal ideation and behaviours after the age of 60 (Batterham et al., 2014; Davis et al., 2009; Shiner et al., 2009). As young people continue to develop mentally, physically and emotionally, coupled with a lack of relationship experience, a move toward suicidal thoughts and behaviours may be indicative of a lack of support mechanisms or under-developed problem-solving skills.

\subsection{Mental health}

From the current review it is difficult to draw conclusions regarding the mediating relationship between mental health issues and relationship factors and their independent or interrelated influence on suicidality. The heterogeneous nature of the studies did 
not allow a consistent view to measure the strength of this relationship. However, research suggests that relationship functioning significantly impacts individual mental-health and overall well-being (Whisman and Baucom, 2012).

A number of the studies suggested that existing mental health issues play an integral role in the increased risk of suicidality with Kõlves et al. (2012) reporting an association between marital and de facto separation, mental illness and suicidality. Busuttil et al. (1994) reported that psychiatric illness accounted for $30.7 \%$ of the reasoning for suicide death, ahead of problems in marriage or relationships. Whisman and Uebelacker (2006) found that relationship discord was associated with elevated risk for mood and anxiety disorders and substance use disorders. However, when controlled for psychiatric disorders, the relationship between discord and suicidal ideation was not significant (Whisman and Uebelacker, 2006).

The idea that culminations of negative life stressors combine to either exacerbate existing mental illness or trigger new illness appears to be a contributory finding arising from this review. Individuals who attempted or completed suicide were observed to have reported higher incidence of external stressors in the year prior to death (Beautrais et al., 1997) with a marked peak of events also culminating in the month prior to the attempt (Paykel et al., 1975). This observation was maintained when compared with control groups (Brent et al., 1993; Zhang and Ma, 2012) and was motivated by the presence of a negative interpersonal life event (Bagge et al., 2013). Furthermore, experiencing an acute negative life event was a trigger for a suicide attempt among individuals not currently planning their attempt, suggesting that clinicians need to be vigilant in monitoring recently assessed 'non-suicidal' individuals if their situation precipitates a likely occurrence of a negative interpersonal life event (Bagge et al., 2013).

Interestingly, Haw and Hawton (2008) observed that for both males and females, those without a psychiatric disorder were more likely to later have a relationship problem compared to those with a psychiatric disorder. This finding was similar to that reported by Logan et al. (2011) who observed that decedents experienced a recent crisis with interpersonal relationship problems in the absence of having a known mental health condition. The occurrence of a psychiatric or personality disorder may engage individuals toward more immediate life issues with a mental health worker already assisting individuals with existing disorders to manage relationship problems. The interrelationship between life stressors and suicide was found to ultimately be dependent on the nature of the stressor and underlying psychiatric disorders (Brent et al., 1993).

\subsection{Methodological considerations}

The studies reviewed were both heterogeneous and broad in nature. Although study quality was not directly assessed, variations in study design, sample size and measurement meant that not all studies were of high quality, which made it difficult to find consistent and comparative patterns within the studies. The measures of intimate partner relationship factors were varied throughout the studies. The majority of studies focused on interpreting self-report information in relation to the status, quality and level of conflict within the interpersonal relationship. The studies included for review had different definitions of intimate partner relationships and this lack of a clear definition made it difficult to generalise and compare results. The inability to distinctly measure the level of relationship quality and define it as a separate variable from personal and/or situational bias interferes with the quality of association made between relationship factors and suicidality. The lack of an operational definition of an intimate partner relationship can create further difficulties when analysing the risk of acute and long-term relationship factors on suicidality.
The measures of suicidality also presented a number of limitations. The majority of studies examining presentations to hospital relied on single self-report items with some studies measuring only presenting suicide attempts and not suicidal ideation. Only nine studies used a more formalised measure of suicidal ideation or attempts. The measures of suicidality also recorded varying time periods from recent to lifetime exposure.

Different inclusion/exclusion criteria were used across the studies making it difficult to isolate intimate partner relationships as a separate factor contributing to suicidality. It is also possible that publication bias was present in the current review, due to the risk that only articles reporting significant results may have been accessible and that the author may have inadvertently not identified all potential papers.

\subsection{Future research}

As intimate partner relationships are an implicit component in the daily lives of many individuals, further research to understand the association between relationship factors, specific target groups (i.e. males, LGBT community) and suicidality is warranted. The creation of a relationship factors interview schedule would allow for a more rigorous overview of the relationships factors involved in the lead up to suicidal ideation and behaviours. Further research examining the association of relationship factors and suicidality from a longitudinal perspective is also necessary to be able to track changes and behavioural developments across time. Specifically, the coherent categorisation of relationship risk factors which differentiate suicidal ideation, attempts and completion.

The need for accessible and effective interventions to support individuals' experiencing suicidal thoughts and/or behaviours following the disruption of an intimate partner relationship, merits further investigation. Due to the proximal nature of a perceived negative intimate partner event and suicidal behaviours, further research aimed at providing more immediate support for individuals experiencing intimate partner relationship problems could also be explored. The integration of new technologies including mobile applications may provide rapid, real-time access to therapeutic interventions.

\subsection{Clinical implications}

Of clinical significance is the finding that interpersonal negative life events involving a romantic partner served as a trigger for engaging in suicidal behaviour for individuals not currently planning an attempt (Bagge et al., 2013). Furthermore, conflicting interpersonal relationships were found to be a significant predictor to multiple suicide attempts (Choi et al., 2013). These findings indicate an increase in suicide risk for individuals who may not present with a typical suicide risk profile. Additionally, the apparent suicidal impulsivity following a negative intimate partner event for younger people (Stephens, 1985) and a marked peak of negative events in the month prior to the suicide attempt, highlights the critical and immediate link between the event and the reaction (Paykel et al., 1971). The emphasis on a brief solution focused therapy outcome may be of particular clinical relevance due to the recency of triggering interpersonal negative life events and the consequent elevation of suicide risk.

Although it is acknowledged that only one study involving the LGBT community was identified, it is important to note the potential clinical relevance in the context of this review. Existing research in the area offers mixed conclusions regarding risk for suicide in LGBT individuals. However, recent research has suggested that sexual minorities are at a higher risk for suicidal behaviours (Skerrett et al., 2015). The increased sense of emotional and relational upheaval due to existing stigma, shame, increased 
risk of substance use and perceived obstacles to support, are clinically important factors to consider when working with members of the LGBT community (McDaniel et al., 2001).

The cross-cultural impact that intimate partner relationships have on suicidality is also of considerable clinical significance. This association transcends cultural and language boundaries in terms of communicating distress, and allows clinicians to have a clear access point to understanding risk factors (separation, disputes, low support etc.

\section{Conclusion}

Intimate partner relationships play an integral role in influencing the development and exacerbation of suicidal ideation, attempts and completion. Results of the review indicate that relationship separation and poor quality relationships are likely to be important risk factors for suicidal thoughts and behaviours and are frequent triggers for a suicide attempt. The strong association between intimate partner relationships and suicidality that has been demonstrated, further emphasises that those people who have indicated that they are experiencing issues with an intimate partner relationships should additionally be screened for suicidal thoughts and behaviours.

\section{References}

Arcel, L.T., Mantonakis, J., Petersson, B., Jemos, J., Kaliteraki, E., 1992. Suicide attempts among Greek and Danish women and the quality of their relationships with husbands or boyfriends. Acta Psychiatr. Scand. 85 (3), 189-195.

Australian Bureau of Statistics. (2012a). Marriages and divorces, Australia, 2011 (cat. 3310.0). Retrieved from 〈http://www.abs.gov.au〉.

Australian Bureau of Statistics. (2012b). Causes of death, Australia, 2012 (cat. 3303.0). Retrieved from 〈http://www.abs.gov.au〉.

Australian Institute for Family Studies. (2014). Family facts and figures: Cohabitation.Retrieved from 〈https://aifs.gov.au/institute/info/charts/cohabitation/in dex.html>.

Australian Institute for Family Studies. (2011). Family facts and figures: Divorce. Retrieved from 〈http://www.aifs.gov.au/institute/info/charts/divorce/〉.

Bagge, C.L., Glenn, C.R., Lee, H.J., 2013. Quantifying the impact of recent negative life events on suicide attempts. J. Abnorm Psychol. 122 (2), 359-368. http://dx.doi org/10.1037/a0030371.

Barber, J.G., Blackman, E.K., Talbot, C., Saebel, J., 2004. The themes expressed in suicide calls to a telephone help line. Soc. Psychiatry Psychiatr. Epidemiol. 39 (2), 121-125. http://dx.doi.org/10.1007/s00127-004-0718-8.

Batterham, P.J., Fairweather-Schmidt, A.K., Butterworth, P., Calear, A.L., Mackinnon, A.J., Christensen, H., 2014. Temporal effects of separation on suicidal thoughts and behaviours. Soc. Sci. Med. 111, 58-63. http://dx.doi.org/10.1016/j. socscimed.2014.04.004

Beautrais, A.L., Joyce, P.R., Mulder, R.T., 1997. Precipitating factors and life events in serious suicide attempts among youths aged 13 through 24 years. J. Am. Acad. Child Adolesc. Psychiatry 36 (11), 1543-1551. http://dx.doi.org/10.1016/ s0890-8567(09)66563-1.

Bonnar, J.W., McGee, R.K., 1977. Suicidal behavior as a form of communication in married couples. Suicide Life Threat. Behav. 7 (1), 7-16.

Bookwala, J., Schulz, R., 1996. Spousal similarity in subjective well-being: the Cardiovascular Health Study. Psychol. Aging 11 (4), 582-590.

Brent, D.A., Perper, J.A., Moritz, G., Baugher, M., Roth, C., Balach, L., Schweers, J., 1993. Stressful life events, psychopathology, and adolescent suicide: A case control study. Suicide Life Threat. Behav. 23 (3), 179-187.

Busuttil, A., Obafunwa, J.O., Ahmed, A., 1994. Suicidal inhalation of vehicular exhaust in the Lothian and Borders region of Scotland. Hum. Exp. Toxicol. 13 (8), 545-550.

Canetto, S.S., Feldman, L.B., Lupei, R.L., 1989. Suicidal persons and their partners: Individual and interpersonal dynamics. Suicide Life Threat. Behav. 19 (3), 237-248.

Canetto, S.S., Lester, D., 2002. Love and achievement motives in women's and men's suicide notes. J. Psychol. 136 (5), 573-576. http://dx.doi.org/10.1080/ 00223980209605552.

Cantor, C.H., Slater, P.J., 1995. Marital breakdown, parenthood, and suicide. J. Fam. Stud. 1 (2), 91-102. http://dx.doi.org/10.5172/jfs.1.2.91.

Carr, D., Freedman, V.A., Cornman, J.C., Schwarz, N., 2014. Happy marriage, happy life? Marital quality and subjective well-being in later life. J. Marriage Fam. 76 (5), 930-948. http://dx.doi.org/10.1111/jomf.12133.

Chia, B.H., Chia, A., Tai, B.C., 2008. Suicide letters in Singapore. Arch. Suicide Res. 12 (1), 74-81. http://dx.doi.org/10.1080/13811110701801069.
Choi, K.H., Wang, S.M., Yeon, B., Suh, S.Y., Oh, Y., Lee, H.K., Lee, K.U., 2013. Risk and protective factors predicting multiple suicide attempts. Psychiatry Res. 210 (3), 957-961. http://dx.doi.org/10.1016/j.psychres.2013.09.026.

Copen, E.C., Daniels, K., Vespa., J., Mosher, W.D., 2012. First marriages in the United States: Data from the 2006-2010 national survey of family growth, National Health Statistic Report, Report No 49.

Cupina, D., 2009. Life events, gender and suicidal behaviours in the acute community setting. Australas. Psychiatry 17 (3), 233-236. http://dx.doi.org/10.1080/ 10398560802680746.

Daradkeh, T.K., Al-Zayer, N., 1988. Parasuicide in an Arab industrial community: The Arabian-American Oil Company experience, Saudi Arabia. Acta Psychiatr. Scand. 77 (6), 707-711.

Davis, M.S., Callanan, V.J., Lester, D., Haines, J., 2009. An inquiry into relationship suicides and reciprocity. Suicide Life Threat. Behav. 39 (5), 482-498. http://dx. doi.org/10.1521/suli.2009.39.5.482.

Devries, K.M., Mak, J.Y., Bacchus, L.J. Child, J.C., Falder, G., Petzold, M., Watts, C.H. 2013. Intimate partner violence and incident depressive symptoms and suicide attempts: a systematic review of longitudinal studies. Plos. Med. 10 (5), e1001439.

Edwards, S.D., Cheetham, R.W., Naidoo, L.R., Griffiths, J.A., 1981. Parasuicide in the Durban Indian community. S Afr. Med. J. 60 (6), 241-243.

Eurostat. (2014). Marriage and divorce statistics. Retreived from $\langle$ http://ec.europa. eu/eurostat/statistics-explained/index.php/Marriage_and_divorce_statistics $\rangle$.

Evans, R., Scourfield, J., Moore, G., 2014. Gender, relationship breakdown, and suicide risk: A review of research in western countries. J. Fam. Issues. . http://dx. doi.org/10.1177/0192513x14562608

Fieldsend, R., Lowenstein, E., 1981. Quarrels, separations and infidelity in the two days preceding self-poisoning episodes. Br. J. Med. Psychol. 54 (1), 349-352. http://dx.doi.org/10.1111/j.2044-8341.1981.tb02573.x.

Harris, E.C., Barraclough, B., 1997. Suicide as an outcome for mental disorders. A meta-analysis. Br. J. Psychiatry 170 (3), 205-228. http://dx.doi.org/10.1192/ bjp.170.3.205.

Haw, C., Hawton, K., 2008. Life problems and deliberate self-harm: Associations with gender, age, suicidal intent and psychiatric and personality disorder. J. Affect. Disord. 109 (1-2), 139-148. http://dx.doi.org/10.1016/j.jad.2007.12.224.

K. Hawton J. Fagg. Suicide, other causes death, attempted suicide 1521988.

Heikkinen, M., Aro, H., Lönnqvist, J., 1992a. The partners' views on precipitant stressors in suicide. Acta Psychiatr. Scand. 85 (5), 380-384. http://dx.doi.org 10.1111/j.1600-0447.1992.tb10323.x.

Heikkinen, M., Aro, H., Lönnqvist, J., 1992b. Recent life events and their role in suicide as seen by the spouses. Acta Psychiatr. Scand. 86 (6), 489-494. http: //dx.doi.org/10.1111/j.1600-0447.1992.tb03303.x.

Hilari, K., Needle, J.J., Harrison, K.L., 2012. What are the important factors in healthrelated quality of life for people with aphasia? A systematic review. Arch. Phys. Med. Rehabil. 93 (1 Suppl), S86-S95. http://dx.doi.org/10.1016/j. apmr.2011.05.028.

Houston, K., Hawton, K., Shepperd, R., 2001. Suicide in young people aged 15-24: A psychological autopsy study. J. Affect. Disord. 63 (1-3), 159-170. http://dx.doi. org/10.1016/S0165-0327(00)00175-0.

Hyman, J., Ireland, R., Frost, L., Cottrell, L., 2012. Suicide incidence and risk factors in an active duty US military population. Am. J. public health 102 (S1), S138-S146.

Ide, N., Wyder, M., Kõlves, K., De Leo, D., 2010. Separation as an important risk factor for suicide: A systematic review. J. Fam. Issues 31 (12), 1689-1716.

Joiner, T., 2005. Why people die by suicide. US: Harvard University Press, Cambridge, MA.

Kaplan, M.S., McFarland, B.H., Huguet, N., Valenstein, M., 2012. Suicide risk and precipitating circumstances among young, middle-aged, and older male veterans. Am. J. public health 102 (S1), S131-S137.

Karch, D.L., Logan, J., McDaniel, D.D., Floyd, C.F., Vagi, K.J., 2013. Precipitating circumstances of suicide among youth aged 10-17 years by sex: Data from the national violent death reporting system, 16 states, 2005-2008. J. Adolesc. Health 53 (1), S51-S53.

Keyvanara, M., Haghshenas, A., 2010. The sociocultural contexts of attempting suicide among women in Iran. Health care women Int. 31 (9), 771-783.

Keyvanara, M., Haghshenas, A., 2011. Sociocultural contexts of attempting suicide among Iranian youth: A qualitative study. EMHJ 17 (6).

Kõlves, K., Ide, N., De Leo, D., 2011. Marital breakdown, shame, and suicidality in men: A direct link? Suicide Life Threat. Behav. 41 (2), 149-159. http://dx.doi. org/10.1111/j.1943-278X.2011.00021x.

Kõlves, K., Ide, N., De Leo, D., 2012. Fluctuations of suicidality in the aftermath of a marital separation: 6-month follow-up observations. J. Affect. Disord. 142 (1), 256-263.

Krajnc, M.S., Schmidt, I., Gregoric, A., Dogsa, I., 1998. Suicide attempts in Slovenian juveniles, 1978-1994. Nord. J. Psychiatry 52 (6), 487-492.

Kurtaş, Ö., Boşgelmez, Sุ., Yaluğ, İ., Birincioğlu, İ., Biçer, Ü., Aker, T., Yahși, S., 2012. The evaluation of suicide letters in Turkey from a cognitive perspective. Crisis: J. Crisis Interv. Suicide Prev. 33 (2), 73-79.

Lester, D., Wood, P., Williams, C., Haines, J., 2004. Motives for suicide-a study of Australian suicide notes. Crisis: J. Crisis Interv. Suicide Prev. 25 (1), 33-34.

Logan, J., Hall, J., Karch, D., 2011. Suicide categories by patterns of known risk factors: A latent class analysis. Arch. Gen. psychiatry 68 (9), 935-941.

Lorensini, S., Bates, G., 2002. Relationship difficulties and unemployment in attempted suicide in an Australian regional center. Psychol. reports 90 (3), 923-929.

Mandal, E., Zalewska, K., 2012. Childhood violence, experience of loss and hurt in close relationships at adulthood and emotional rejection as risk factors of suicide attempts among women. Arch. Psychiatry Psychother. 3, 45-50. 
Markey, C., Markey, P., Gray, H., 2007. Romantic relationships and health: An examination of individuals' perceptions of their romantic partners' influences on their health. Sex. Roles 57 (5-6), 435-445. http://dx.doi.org/10.1007/ s11199-007-9266-5.

Martin, J.S., Ghahramanlou-Holloway, M., Englert, D.R., Bakalar, J.L., Olsen, C., Nademin, E.M., Branlund, S., 2013. Marital status, life stressor precipitants, and communications of distress and suicide intent in a sample of United States Air Force suicide decedents. Arch. suicide Res. 17 (2), 148-160.

McDaniel, J.S., Purcell, D., D'Augelli, A.R., 2001. The relationship between sexual orientation and risk for suicide: Research findings and future directions for research and prevention. Suicide Life -Threat. Behav. 31 (1), 84-105.

McLaughlin, J., O'Carroll, R., O'Connor, R., 2012. Intimate partner abuse and suicidality: A systematic review. Clin. Psychol. Rev. 32 (8), 677-689.

National Centre for Health Statistics. (2012). National marriage and divorce rate trends.Retrieved from $\langle$ http://cdc.gov/nchs $\rangle$.

Osvath, P., Vörös, V., Fekete, S., 2003. Life events and psychopathology in a group of suicide attempters. Psychopathology 37 (1), 36-40.

Owens, D., Horrocks, J., House, A., 2002. Fatal and non-fatal repetition of self-harm. Syst. Rev. 181 (3), 193-199. http://dx.doi.org/10.1192/bjp.181.3.193.

Paykel, E.S., Prusoff, B.A., Myers, J.K., 1975. Suicide attempts and recent life events: A controlled comparison. Arch. Gen. psychiatry 32 (3), 327-333.

Paykel, E.S., Prusoff, B.A., Uhlenhuth, E., 1971. Scaling of life events. Arch. Gen. psychiatry 25 (4), 340-347.

Popay, J., Roberts, H., Sowden, A., Petticrew, M., Arai, L., Rodgers, M., et al., 2006. Guidance on the conduct of narrative synthesis in systematic reviews, Final Report Lancaster, Institute of Health Research. ESRC Methods Programme, Lancaster.

Robles, T.F., Kiecolt-Glaser, J.K., 2003. The physiology of marriage: Pathways to health. Physiol. Behav. 79 (3), 409-416. http://dx.doi.org/10.1016/S0031-9384 (03)00160-4.

Runyan, C.W., Moracco, K.E., Dulli, L., Butts, J., 2003. Suicide among North Carolina women, 1989-93: information from two data sources. Inj. Prev. 9 (1), 67-72.

Sandberg-Thoma, S.E., Kamp Dush, C.M., 2014. Indicators of adolescent depression and relationship progression in emerging adulthood. J. Marriage Fam. 76 (1), 191-206.

Séguin, M., Beauchamp, G., Robert, M., DiMambro, M., Turecki, G., 2014. Developmental model of suicide trajectories. Br. J. Psychiatry 205 (2), 120-126.

Shiner, M., Scourfield, J., Fincham, B., Langer, S., 2009. When things fall apart: Gender and suicide across the life-course. Soc. Sci. Med. 69 (5), 738-746.

Skerrett, D.M., Kõlves, K., De Leo, D., 2014. Suicides among lesbian, gay, bisexual, and transgender populations in Australia: An analysis of the Queensland Suicide Register. Asia-Pacific Psychiatry 6 (4), 440-446.

Skerrett, D.M., Kõlves, K., De Leo, D., 2015. Are LGBT populations at a higher risk for suicidal behaviours in Australia? Research findings and implications. J. Homosex. 62 (7), 883-901.

Soller, B., 2014. Caught in a Bad Romance Adolescent Romantic Relationships and Mental Health. J. Health Soc. Behav. 55 (1), 56-72.

Stack, S., Scourfield, J., 2015. Recency of divorce, depression, and suicide risk. J. Fam. Issues 36 (6), 695-715. http://dx.doi.org/10.1177/0192513x13494824.

Stephens, B.J., 1985. Suicidal women and their relationships with husbands, boyfriends, and lovers. Suicide Life -Threat. Behav. 15 (2), 77-90.

Tavite, A., Tavite, S., 2009. Suicide in the Tokelau islands. Pac. health dialog 15 (2), 67-83.

Van Orden, K.A., Witte, T.K., Cukrowicz, K.C., Braithwaite, S., Selby, E.A., Joiner, T.E., 2010. The interpersonal theory of suicide. Psychol. Rev. 117 (2), 575-600. http: //dx.doi.org/10.1037/a0018697.

Weyrauch, K.F., Roy-Byrne, P., Katon, W., Wilson, L., 2001. Stressful life events and impulsiveness in failed suicide. Suicide Life -Threat. Behav, 31 (3), 311-319.

Whisman, M., Baucom, D., 2012. Intimate Relationships and Psychopathology. Clin Child. Fam. Psychol. Rev. 15 (1), 4-13. http://dx.doi.org/10.1007/ s10567-011-0107-2.

Whisman, M.A., 2013. Relationship discord and the prevalence, incidence, and treatment of psychopathology. J. Soc. Pers. Relationships 30 (2), 163-170. http: //dx.doi.org/10.1177/0265407512455269.

Whisman, M.A., Uebelacker, L.A., 2006. Impairment and distress associated with relationship discord in a national sample of married or cohabiting adults. J. Fam. Psychol. 20 (3), 369

Whisman, M.A., Uebelacker, L.A., 2009. Prospective associations between marital discord and depressive symptoms in middle-aged and older adults. Psychol. Aging 24 (1), 184-189. http://dx.doi.org/10.1037/a0014759.

World Health Organisation. (2012). Mental health: Suicide Data. Retrieved from 〈http://www.who.int/mental_health/prevention/suicide/suicideprevent/en/〉.

Wyder, M., Ward, P., De Leo, D., 2009. Separation as a suicide risk factor. J. Affect. Disord. 116 (3), 208-213.

Yaseen, Z.S., Fisher, K., Morales, E., Galynker, I.I., 2012. Love and suicide: the structure of the affective intensity rating scale (AIRS) and its relation to suicidal behavior. Plos ONE 7 (8), e44069.

Zhang, J., Ma, Z., 2012. Patterns of life events preceding the suicide in rural young Chinese: A case control study. J. Affect. Disord. 140 (2), 161-167. 